\title{
Variations in orthodontic bracket retention related to base design. Comparison of foil mesh and anchor pylons brackets
}

\section{Różnice w retencji zamków ortodontycznych w zależności od budowy podstawy. Porównanie zamków z siateczką retencyjną i zamków z podstawą integralną}

\author{
Marta Gibas-Stanek ${ }^{1}$, Stephen Williams ${ }^{1}$, Wojciech I. Ryniewicz ${ }^{2}$, \\ Bartlomiej W. Loster ${ }^{1}$ \\ ${ }^{1}$ Katedra Ortodoncii, Instyłut Stomatologii, Wydział Lekarski, Uniwersytet Jagielloński Collegium Medicum, Kraków, Polska \\ Department of Orthodontics, Dental Institute, Faculty of Medicine, Jagiellonian University Medical College, Cracow, Poland \\ Head: prof. B.W. Loster \\ 2 Katedra Protetyki Stomatologicznej, Instyłut Stomatologii, Wydział Lekarski, Uniwersytet Jagielloński Collegium Medicum, Kraków, Polska \\ Department of Dental Prosthetics, Dental Institute, Faculty of Medicine, Jagiellonian University Medical College, Cracow, Poland \\ Head: dr hab. G. Wiśniewska
}

\begin{abstract}
Aim of the study. To compare the shear bond strength of metal brackets with foil mesh (3M, Victory Series), one piece metal brackets (Cannon Ultra) and aesthetic plastic brackets (Cannon Ultra) and to evaluate the sandblasting effect on previously used metal bracket bases regarding their bonding ability. Materials and Methods.A total of seventy human third molars were divided into four groups, and brackets were bonded to the enamel using Transbond XT. After 24 hours of storage, brackets were debonded with Instron Universal Testing Machine ${ }^{\circledR}$ and shear bond strength was recorded. Metal brackets were sandblasted until all visible bonding material was removed from the bracket base and then the bonding procedure and shear bond testing were repeated. Shapiro-Wilk test was used to check normal distribution. Student's t-test was used to compare the shear bond strength. Results. The shear bond strength of one-piece metal brackets is significantly bigger (18.93MPa) than metal brackets with foil mesh (12.53MPa). Metal brackets in general demonstrate better bonding properties than aesthetic plastic brackets $(8.61 \mathrm{MPa})$. There is no statistically significant difference in shear bond strength between
\end{abstract}

\section{KEYWORDS:}

shear bond strength, foil mesh, anchor pylons

\section{Streszczenie}

Cel badania. Porównanie wielkości sit ścinających zamków metalowych z siateczka retencyjna (3M, Victory Series), metalowych zamków z podstawa integralna (Cannon Ultra) oraz plastikowych zamków estetycznych (Cannon Ultra) oraz ocena wplywu piaskowania uprzednio użytych zamków metalowych na ich właściwości adhezyjne. Material i metoda. 70 ludzkich trzecich zębów trzonowych podzielono na 4 grupy oraz przyklejono do szkliwa zamki stosujac materiat Transbond XT. Po 24 godzinach przechowywania zamki oderwano za pomoca Uniwersalnej Maszyny Testujacej Instron ${ }^{\circledR}$ oraz zarejestrowano wielkość sit ścinajacych. Następnie metalowe zamki zostaty wypiaskowane do momentu usunięcia catego widocznego kleju, ponownie przyklejone do szkliwa oraz poddane badaniu wielkości sit ścinajacych. W celu zbadania rozkładu normalnego zastosowano test Shapiro-Wilka. Dla porównania wartości napięcia ścinającego użyto testu t-Studenta. Wyniki. Sita ścinajaca dla metalowych zamków z podstawa integralna jest znaczaco większa (18,93MPa) niz dla zamków metalowych z siateczka retencyjna $(12,53 \mathrm{MPa})$. Zamki metalowe wykazuja

\section{HAStA INDEKSOWE:}

siła ścinająca, siateczka retencyjna, podstawa integralna 
new and re-used sandblasted brackets. Conclusions. One-piece brackets with anchor pylons demonstrate better bonding properties but there is a higher risk of enamel damage during debonding of re-used sandblasted brackets. lepsze właściwości adhezyjne $w$ porównaniu z plastikowymi zamkami estetycznymi (8,61MPa). Nie ma istotnej statystycznie różnicy $w$ wielkości sit ścinajacych między zamkami nowymi oraz użytymi zamkami poddanymi piaskowaniu. Wnioski. Zamki z podstawa integralna wykazują lepsze właściwości adhezyjne, jednak istnieje większe ryzyko uszkodzenia szkliwa $w$ przypadku zamków użytych ponownie po wypiaskowaniu podstawy.

\section{Wstęp}

Retencja zamków ortodontycznych do powierzchni zębów stanowi jeden $\mathrm{z}$ istotniejszych czynników decydujących o powodzeniu leczenia ortodontycznego.

Podczas gdy wiele uwagi poświęca się bezpiecznemu usuwaniu zamków bez uszczerbku dla tkanek zęba, to właśnie utrata zamków w trakcie terapii stanowi główne zagrożenie dla uzyskania celu leczenia. ${ }^{1}$ Faktyczna retencja zamków ortodontycznych zależy od dwóch głównych czynników: (1) retencyjnych właściwości materiału adhezyjnego w stosunku do podstawy zamka, (2) siły wiązania, adhezji oraz stabilności użytego materiału. ${ }^{2-5} \mathrm{~W}$ przypadku, kiedy podczas leczenia stosowane są zamki kompozytowe, zostaje włączony trzeci czynnik (3): chemiczne wiązanie pomiędzy podstawą zamka a materiałem adhezyjnym. Połączenie chemiczne nie występuje w przypadku stosowania zamków metalowych.

W praktyce zerwanie połączenia między powierzchnią zęba a zamkiem, czego skutkiem jest utrata zamka, może mieć miejsce na 4 poziomach:

(1) pomiędzy szkliwem a materiałem adhezyjnym. Dotyczy to zarówno połączenia chemicznego, jak i fizycznego pomiędzy zastosowanym materiałem adhezyjnym a wytrawioną powierzchnią szkliwa.

(2) pomiędzy materiałem adhezyjnym a podstawą zamka. W większości przypadków dotyczy połączenia czysto mechanicznego, ale w przypadku zamków kompozytowych zrywane są również wiązania chemiczne.

(3) w obrębie materiału adhezyjnego. Ten czynnik uzależniony jest od trwałości użytego materiału adhezyjnego i wpływa na siłę wiązania poprzez jego właściwości fizyczne takie jak gę- 
thickness of the material ${ }^{5,6}$ as well as the method of curing (i.e. self- or light-curing). ${ }^{7}$

(iv) intra-enamel. This factor relates to the risk that, in connection with a very strong bond, strong forces possibly arising from mastication, will result in a physical enamel fracture.

Regarding the design and manufacture of the brackets, a number of design details can be employed in order to increase retention, including the incorporation of a "net" or "foil" onto the base of the bracket, into which the adhesive can flow before setting. This system is frequently employed in the manufacture of "two-piece" brackets where the retention wings are brazed on to the metal base on the other side of which the (frequently etched) retention foil is attached.

In the case of "one-piece" brackets it is often chosen to increase adhesive retention by cutting undercut channels in the "tooth surface" of the bracket, a system that is also employed in connection with the production of composite brackets. As an alternative, in the case of metal one-piece brackets, physical adhesive retention can be supplemented by the incorporation of a series of the so-called "pylons" into the casting of the base, creating undercut irregular areas into which it is anticipated that the adhesive can flow.

In addition to the specific practical details outlined above a number of other factors influence bracket/tooth bond strength including the type of adhesive (composite material appears to be stronger than glass ionomer cement ${ }^{5}$ ), enamel conditioning procedures, age of the patient ${ }^{8}$ as well as the isolation of the tooth from saliva during bracket bonding.

Previous reports suggest that the most frequent bonding fracture site is between the bracket and the cement ${ }^{3,4}$ though a number of reports also demonstrate that in some cases of bracket loss much of the adhesive appears to be attached to the bracket, with very little remaining on the tooth surface. 6

The brackets for which bonding characteristics were studied in the present report were "Cannon Ultra ${ }^{\circledR}$ ”, represented by both metal and composite types. The Cannon Ultra ${ }^{\circledR}$ bracket is a twin-slot bracket combining the properties of a standard stość 5,6 czy metoda polimeryzacji (np. materiały chemo- i światłoutwardzalne). ${ }^{7}$

(4) w obrębie szkliwa. Ten czynnik związany jest $\mathrm{z}$ ryzykiem, że duże siły wiązania w połączeniu ze znacznymi siłami wywieranymi podczas żucia doprowadzą do fizycznych uszkodzeń szkliwa.

Biorąc pod uwagę budowę oraz metodę wytwarzania zamków ortodontycznych, stosowanych jest wiele metod zwiększania retencji, między innymi wbudowywanie w podstawę zamka siateczki retencyjnej, w którą materiał adhezyjny zapływa przed związaniem. Ten system jest często stosowany w produkcji zamków dwuczęściowych, gdzie skrzydełka retencyjne zostają przylutowane do jednej strony metalowej podstawy, a siateczka retencyjna (często dodatkowo wytrawiona) do drugiej. W przypadku zamków jednoczęściowych retencja materiału adhezyjnego jest zwiększana przez wycinanie na powierzchni zamka zwróconej w stronę szkliwa rynienek retencyjnych. System ten jest także popularny przy wytwarzaniu zamków kompozytowych. Jako alternatywę, w przypadku jednoczęściowych zamków metalowych, dla zwiększenia adhezji fizycznej można zastosować tak zwane słupki retencyjne. W tym przypadku oczekuje się zapływania materiału w obszar nieregularnych podcięć rozmieszczonych w obrębie podstawy zamka.

Na siłę wiązania pomiędzy zamkiem a zębem wpływa, oprócz czynników wymienionych, wiele innych zmiennych, takich jak rodzaj użytego materiału adhezyjnego (materiały kompozytowe wykazują wyższe siły wiązania niż cement glasjonomerowy), ${ }^{5}$ proces wytrawiania szkliwa, wiek pacjenta, ${ }^{8}$ a także izolacja zęba od dostępu śliny podczas zabiegu przyklejania aparatu.

Poprzednie badania wskazują, że najczęściej dochodzi do zerwania połączenia pomiędzy zamkiem a cementem, ${ }^{3,4}$ chociaż kilka $\mathrm{z}$ nich opisuje przypadki odrywania zamków, gdzie większa część materiału adhezyjnego pozostawała na podstawie zamka, a tylko niewielka jego ilość na szkliwie. ${ }^{6}$

Zamki, których właściwości badano w niniejszej pracy to metalowe i kompozytowe zamki systemu "Cannon Ultra ${ }^{\circledR}$ ". Cannon Ultra ${ }^{\circledR}$ jest 


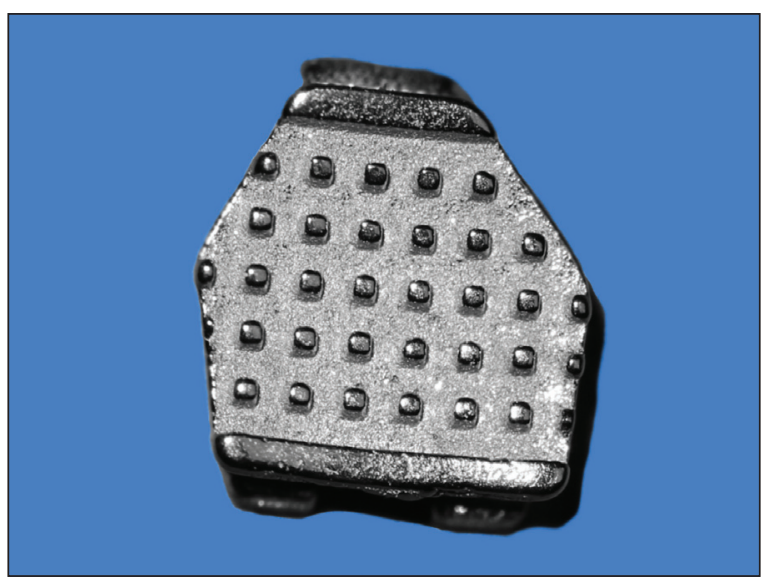

Fig. 1. Cannon bracket base with anchor pylons.

Podstawa zamka Cannon z stupkami retencyinymi.

edgewise bracket with the low friction properties related to the Begg Technique. ${ }^{9}$ The bracket is available as a one-piece metal bracket or as a composite bracket. Concerning retention features, in the case of the one-piece metal brackets retention is supplemented by pylons cast into the base whereas the composite brackets were equipped with intra-base undercut retention grooves. The increasing popularity of the latter type of brackets makes a study of the retention characteristics necessary.

The aim of present study was to compare the shear bond strength of steel and composite versions of the Cannon Ultra ${ }^{\circledR}$ bracket with standard metal brackets (Victory ${ }^{\circledR} 3 \mathrm{M}$ Unitec). In order to replicate normal in vivo conditions as much as possible the brackets were mounted on the enamel surface of extracted human teeth using a standardized procedure involving a type of adhesive regularly employed in clinical use (Transbond $\mathrm{XT}^{\circledR}$ ).

Since re-use of brackets which have been lost during treatment is an accepted clinical procedure the study would also consider the effect of a "sand blasting" technique on retention properties of the brackets involved.

The working hypothesis for the present study was that the efficiency of the retention properties of orthodontic brackets is related to the physical nature of the bracket base and could also, in the case of recycling of loosened brackets, be improved by techniką wykorzystującą podwójny slot, łączącą właściwości standardowych zamków ze slotem krawężnym oraz niskotarciowych zamków metody Begga. ${ }^{9}$ Zamki te dostępne są jako jednoczęściowe zamki metalowe lub kompozytowe. Biorąc pod uwagę właściwości retencyjne, metalowe zamki jednoczęściowe zaopatrzone są w tak zwane słupki retencyjne, podczas gdy podstawa zamków kompozytowych zawiera podcięcia w postaci rynienek. Rosnąca popularność zamków tego systemu niesie potrzebę zbadania ich właściwości retencyjnych.

Celem badania było porównanie sił ścinających działających na metalowe oraz kompozytowe zamki systemu Cannon Ultra ${ }^{\circledR}$ ze standardowymi zamkami metalowymi (Victory ${ }^{\circledR} 3 \mathrm{M}$ Unitec). Aby jak najwierniej odtworzyć warunki in vivo, zamki przyklejano do szkliwa usuniętych ludzkich zębów z wykorzystaniem materiału adhezyjnego stosowanego na co dzień w pracy klinicznej (Transbond $\mathrm{XT}^{\circledR}$ ).

Ponieważ ponowne użycie zamków odklejonych podczas leczenia jest akceptowalną procedurą, w badaniu sprawdzono także efekt piaskowania zamków uprzednio wykorzystanych do badania ich właściwości retencyjnych.

Hipotezą roboczą dla badania było założenie, że właściwości retencyjne zamków ortodontycznych są związane $\mathrm{z}$ budową fizyczną jego podstawy oraz mogą być poprawione podczas procesu piaskowania przygotowującego zamek do ponownego użycia.

\section{Material i metoda}

Do celów badania zamki przyklejono do usuniętych naturalnych zębów. Wykorzystano 70 ludzkich trzecich zębów trzonowych (z nienaruszonym szkliwem, niepoddawanych uprzednio działaniu żadnych substancji chemicznych, bez uszkodzeń związanych z ekstrakcją oraz bez próchnicy), które oczyszczono z tkanek miękkich oraz przechowywano $\mathrm{w}$ wodzie wodociągowej $\mathrm{w}$ temperaturze pokojowej.

W eksperymencie zbadano 4 rodzaje zamków:

(1) metalowe zamki Cannon Ultra dla zęba 21 (20 zamków), wybrane z powodu relatywnie dużej i płaskiej podstawy, 
a sand blasting procedure used in connection with bracket renovation.

\section{Material and methods}

For the purposes of the study brackets were mounted on extracted natural teeth. For this purpose, seventy recently extracted human third molars (with intact buccal enamel, no history of any pre-treatment with chemical agents, no cracks during extraction and no caries) were cleansed of soft tissue and stored in tap water at room temperature.

Four types of bracket were used in the study:

(i) Cannon Ultra metal brackets for tooth 21 (twenty pieces), chosen because of the relatively large and flat base,

(ii) Cannon Ultra metal brackets for tooth 33 (ten pieces), chosen since this particular bracket seems, on the basis of clinical experience, to be most prone to bonding failure. These brackets were also included since they represent brackets with a curved base,

(iii) Victory metal brackets ( ${ }^{\circledR} 3 \mathrm{M}$ Unitec) for tooth 21 (twenty pieces), chosen as representative of a "standard" edgewise type of bracket of good quality,

(iv) Cannon Ultra aesthetic brackets for tooth 21 (twenty pieces), chosen since these brackets are made of a composite material and could therefore be expected to demonstrate different retention properties.

Each tooth was embedded in cold-curing, fastsetting acrylic with the labial and lingual surface exposed above the cementum-enamel junction, the surface being perpendicular to the base of the block. The samples are divided into four groups, twenty teeth in groups 1,3,4 and ten teeth in group 2 as below:

Group 1) twenty Cannon Ultra metal brackets (for tooth 21)

Group 2) ten Cannon Ultra metal bracket (for tooth 33)

Group 3) twenty Victory metal brackets (3M Unitec) (for tooth 21)

Group 4) twenty Cannon Ultra aesthetic bracket (for tooth 21)
(2) metalowe zamki Cannon Ultra dla zęba 33 (10 zamków), wybrane z powodu częstej ich utraty podczas stosowania klinicznego. Zamki te zostały także wybrane jako reprezentujące zamki z podstawą zakrzywioną,

(3) metalowe zamki Victory ( ${ }^{\circledR} 3 \mathrm{M}$ Unitec) dla zęba 21(20 zamków), wybrane jako reprezentacja standardowych, dobrej jakości zamków edgwise,

(4) estetyczne zamki Cannon Ultra dla zęba 21 (20 zamków), wybrane ponieważ jako zamki kompozytowe mogą posiadać odmienne właściwości retencyjne.

Każdy ząb został zatopiony w wiążącym na zimno szybko polimeryzującym akrylu do poziomu połączenia szkliwno-cementowego powierzchni policzkowej i językowej, tak aby powierzchnie te były prostopadłe do podstawy bloczka akrylowego.

Próbki podzielono na 4 grupy, po 20 zębów w grupach 1,3,4 oraz 10 zębów w grupie 2:

Grupa 1) 20 metalowych zamków Cannon Ultra (dla zęba 21).

Grupa 2) 10 metalowych zamków Cannon Ultra (dla zęba 33).

Grupa 3) 20 metalowych zamków Victory (3M Unitec) (dla zęba 21).

Grupa 4) 20 estetycznych zamków Cannon Ultra (dla zęba 21).

\section{Procedura przyklejania zamków}

Policzkowa powierzchnia wszystkich próbek została oczyszczona przez $10 \mathrm{~s}$ za pomocą profilaktycznej gumki polerskiej oraz pozbawionego fluoru pumeksu i wody, następnie spłukana przez 10 sekund sprejem wodnym oraz wysuszona powietrzem z wykorzystaniem standardowej dmuchawko-strzykawki.

Powierzchnię zęba wytrawiono przez 30 sekund żelem zawierającym $37 \%$ kwas fosforowy, aplikowanym na powierzchnię policzkową. Następnie zęby płukano sprejem wodnym przez 30 sekund oraz osuszano powietrzem przez 20 sekund.

Wszystkie zamki zostały przyklejone do przygotowanej powierzchni z użyciem systemu adhezyjnego Transbond XT (®3M Unitec) zgodnie z zaleceniami producenta. Następnie za pomocą pincety ortodontycznej zamki zostały umieszczo- 


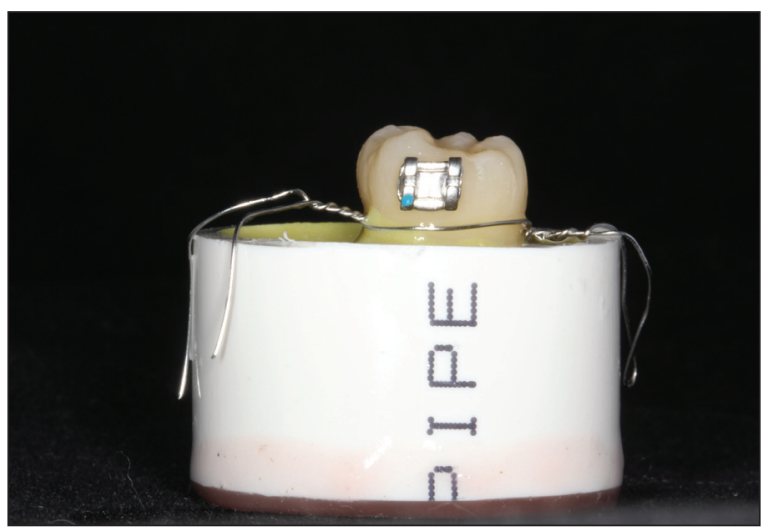

Fig. 2. Sample (tooth with bracket embeded in the acrylic block). Próbka (ząb z zamkiem zatopiony w akrylowym bloczku).

\section{Bonding procedure}

The buccal surfaces of all specimens were polished with a mixture of water and fluoridefree pumice in a rubber prophylactic cup for 10 seconds, rinsed with a water spray for 10 seconds and subsequently dried with air from a standard triple spray.

The tooth surface was etched by means of a $37 \%$ phosphoric acid gel applied to the buccal surface of each tooth for 30 seconds. The teeth were then rinsed with a water spray for 30 seconds and air dried for 20 seconds. All brackets were bonded to the prepared tooth surfaces with Transbond XT adhesive system (®3M Unitec) used in accordance with the manufacturer's instructions.

The brackets were then properly positioned on the tooth with bracket tweezers and finally pressed onto the tooth surface with a force of $300 \mathrm{~g}$ using the tip of a Correx force gauge $\AA$. Excess adhesive was removed by means of a sharp probe and the bracket subsequently light-cured for 40 seconds (10 sec. on each side of the bracket).

\section{Shear bond testing}

The specimens were stored for 24 hours in tap water at room temperature. The testing procedure consisted of the application of an occluso-gingival load to the bracket using an Instron ${ }^{\circledR}$ "Universal Testing Machine" as shown in Figure 4. The machine consists of stable lower unit, where the test sample is held in a rigid position and subjected

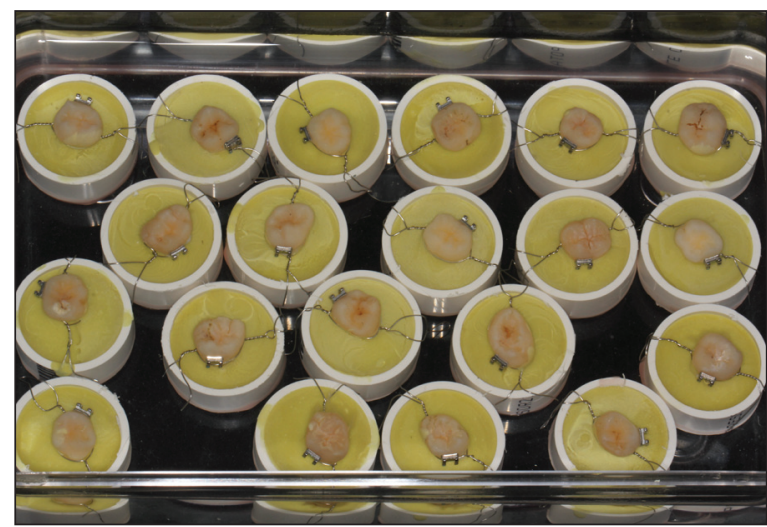

Fig. 3. Samples prepared for testing. Próbki przygotowane do badania.

ne na powierzchni zęba oraz dociśnięte końcówką siłomierza Correx® siłą 300g. Nadmiar kleju usunięto zgłębnikiem, a zamki naświetlono lampą polimeryzacyjną przez 40 sekund (10 sekund z każdej strony zamka).

\section{Pomiar sily ścinającej}

Próbki przechowywano przez 24 godziny w wodzie wodociągowej, w temperaturze pokojowej. Procedura pomiaru polegała na przyłożeniu do zamka obciążenia działającego w kierunku okluzyjno-dziąsłowym z zastosowaniem uniwersalnej maszyny testującej Instron ${ }^{\circledR}$, przedstawionej na rycinie 4. Urządzenie zbudowane jest z nieruchomej części dolnej, gdzie próbka ulokowana jest w stabilnym położeniu i poddawana jest działaniu siły wywieranej przez ruchomą jednostkę górną, przesuwającą się z prędkością 0,5 $\mathrm{mm} / \mathrm{min}$. Wyniki (w Newtonach) rejestrowane w momencie oderwania zamka od powierzchni zęba zapisywane były przez powiązany z maszyną system komputerowy. Otrzymane wyniki przekształcono w megapaskale $\left(\mathrm{MPa}=10^{6} \mathrm{~Pa}\right) \mathrm{ko}-$ rzystając ze wzoru:

$$
\mathrm{R}=\mathrm{F} / \mathrm{A}
$$

gdzie "R" to napięcie ścinające w MPa, "F" siła wywołująca oderwanie zamka w Newtonach oraz "A" powierzchnia zamka w $\mathrm{mm}^{2}$. 


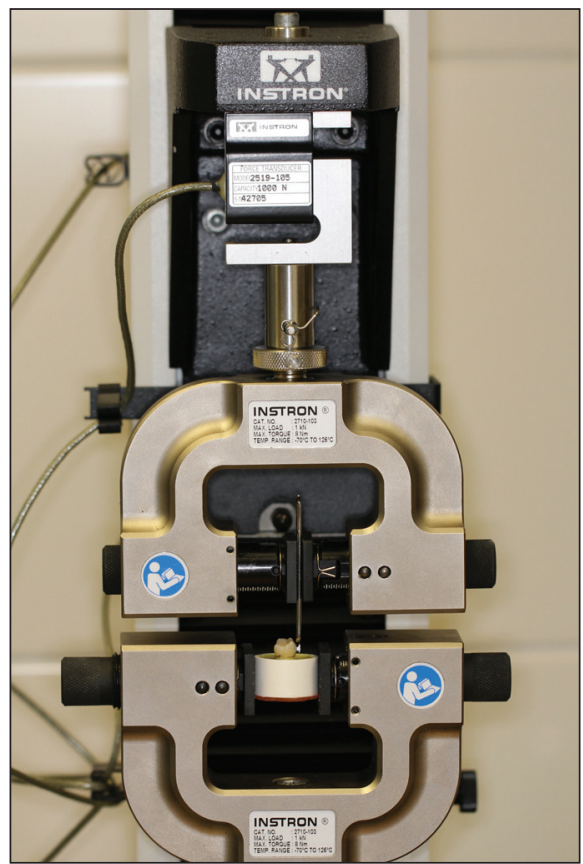

Fig. 4. Instron Universal Testing Machine $®$ - descripion of the machine in text of the article.

Uniwersalna Maszyna Testuigca Instron® - opis urzadzenia w tekście artykutu.

to force by an upper movable unit, acting with the speed of $0.5 \mathrm{~mm} / \mathrm{min}$. Results (in Newtons) were recorded on a connected computer system at the moment of debonding of the bracket. Results were converted to megapascals $\left(\mathrm{MPa}=10^{6} \mathrm{~Pa}\right)$ by means of the formula:

$$
\mathrm{R}=\mathrm{F} / \mathrm{A}
$$

where " $R$ " represents shear bond strength in $\mathrm{MPa}$, "F" the breaking load or debonding force in Newtons and "A" the bracket base area in $\mathrm{mm}^{2}$.

\section{The effect of sand blasting (aluminium oxi- de) abrasion on debonded metal brackets}

Re-used brackets from group 1 (twenty brackets), 2 (ten brackets) and 3 (twenty brackets) were subjected to aluminium oxide abrasion prior to remounting and subsequent retesting. Using a sandblasting machine (AIRSONIC®, Hager Werken), the bracket bases were held approximately at $5.0 \mathrm{~mm}$ from the tip of the device and cleaned with $50 \mu \mathrm{m}$ aluminum oxide until all

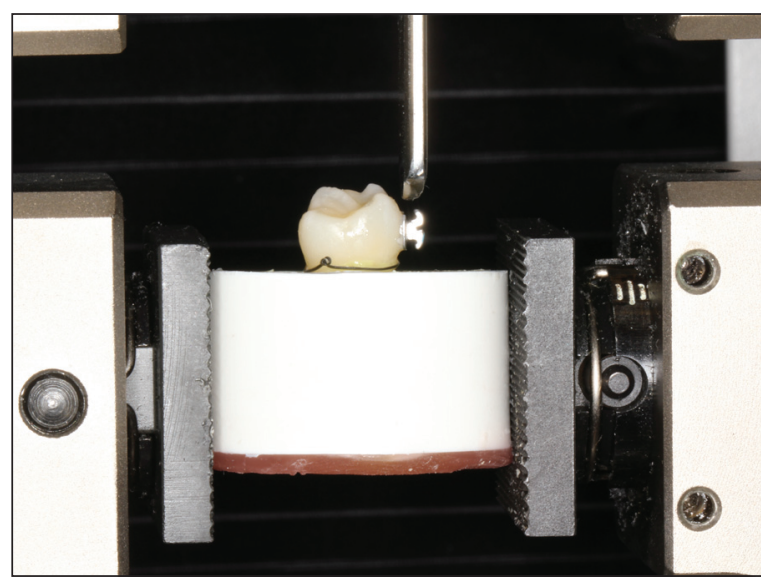

Fig. 5. Shear bond testing. Badanie sity ścinajacej.

Badanie efektu piaskowania (tlenkiem glinu) oderwanych zamków

Odklejone zamki z grupy 1 (20 zamków), 2 (10 zamków) oraz 3 (20 zamków) poddano piaskowaniu, a następnie ponownemu przyklejeniu i badaniu w maszynie testującej. Podstawy zamków oczyszczono z całego widocznego materiału wiążącego używając piaskarki AIRSONIC® Hager Werken oraz $50 \mu \mathrm{m}$ tlenku glinu, zachowując między podstawą zamka a końcówką urządzenia odległość 5.0mm. Następnie zamki przez 1 min „odttuszczono" zanurzając je w alkoholu etylowym oraz przyklejono do nieuszkodzonego szkliwa. Po 24 godzinach przechowywania w wodzie wodociągowej powtórzono pomiar napięcia ścinającego, a otrzymane wyniki wykorzystano do porównania siły uzyskanej przed oraz po wypiaskowaniu.

Po oderwaniu zamków makroskopowo oceniono miejsce zerwania połączenia oraz rozmieszczenie materiału wiążącego. Aby ocenić ilość pozostałego na podstawie zamka kleju, zastosowano wskaźnik ARI oraz empiryczną wzrokową ocenę. 
visible bonding material was removed from the bracket base. The brackets were then 'degreased' in ethyl alcohol for 1 minute and bonded on intact enamel.

After 24 hours of storage in tap water at room temperature, the shear bond test was repeated making a comparison of bracket bond-strength values, with and without sandblasting. After debonding, the mode of bond failure was analyzed macroscopically, and the locations of the residual bonding material were determined. The adhesive remnant index (ARI) was used to assess the amount of adhesive left on the bracket base after debonding estimated by empirical optical inspection.

$* 0$ - less than $10 \%$ of adhesive remaining on bracket;

$* 1$-more than $10 \%$ but less than $50 \%$ remaining on bracket;

$* 2$ - more than $50 \%$ but less than $90 \%$ left on bracket;

$* 3$ - more than $90 \%$ of adhesive remaining on the bracket. ${ }^{(3)}$

\section{Statistical analysis of the material}

The results of the evaluation of the shear bond strengths were collected and analyzed statistically using SPSS Statistics v19®. Descriptive statistics for each group were generated including the mean, maximum and minimum values as well as the standard deviation. The normality of the distribution of the various groups was tested by means of a Shapiro-Wilk test ${ }^{10}$ and homogeneity of variance of the experimental groups was investigated by means of Levene's test. ${ }^{11}$

A Student's t-test $\mathrm{t}^{12}$ was used to compare mean values of each of the 7 groups observed using group 1 (the Cannon steel incisor brackets) as the group with which the other test groups were compared.

\section{Results}

The results of the experimental procedure can be seen in Tables 1 and 2 where Table 1 presents the comparison between the four experimental groups, and Table 2 provides information concerning the results of the experiment using the sand-blasted (re-used) brackets. *0-mniej niż 10\% materiału łączącego pozostało na podstawie zamka;

*I- więcej niż $10 \%$, ale mniej niż $10 \%$ pozostało na podstawie zamka;

*2 - więcej niż $50 \%$, ale mniej niż $90 \%$ pozostało na podstawie zamka;

*3 - więcej niż 90\% materiału łączącego pozostało na podstawie zamka. ${ }^{3}$

\section{Analiza statystyczna materiału}

Wyniki badania siły ścinającej zgromadzono oraz przeanalizowano za pomocą programu SPSS Statistics v19®. Dla każdej grupy wygenerowano statystykę opisową uwzględniającą średnią, wartość maksymalną i minimalną oraz odchylenie standardowe. Normalność rozkładu sprawdzono testem Shapiro-Wilka ${ }^{10}$, a jednorodność wariancji zbadano testem Levena. ${ }^{11}$

Dla porównania 7 grup doświadczalnych zastosowano test t Studenta ${ }^{12}$ stosując grupę 1 (metalowe zamki Cannon na ząb sieczny) jako tę, do której porównywano pozostałe zamki.

\section{Wyniki}

Rezultaty eksperymentu zaprezentowane są w tabelach 1 i 2, gdzie tabela 1 odnosi się do porównania czterech badanych grup zamków, a tabela 2 dostarcza wyników dotyczących badania z zastosowaniem zamków poddanych piaskowaniu (użytych powtórnie).

Przyjmując wyniki testów Shapiro-Wilka i Levena zastosowano dla porównania prób niezależnych test t-Studenta, czego rezultat zaprezentowano jako wartość t oraz liczbowy poziom istotności statystycznej.

W pierwszej grupie, w której badano zamki Cannon, średnia siła ścinająca wynosiła 18,93 $\mathrm{MPa}$, aczkolwiek z bardzo znaczną rozpiętością wynosząca od 4.43MPa do 42.27 MPa. W przypadku wyników dla dolnego kła reprezentowanych przez grupę 2 wartość średnia była niższa, niż w grupie $1 \mathrm{i}$ wynosiła11.97 MPa, ale ponownie wystąpił duży rozrzut wyników od $3.35 \mathrm{MPa}$ do $30.57 \mathrm{MPa}$. Nie znaleziono statystycznie istotnej różnicy pomiędzy tymi grupami ( $\mathrm{t}=1.86 \mathrm{~ns})$. Siła ścinająca w przypadku trzeciej grupy, zawierającej zamki bardziej typowe dla techniki edgwise (3M 
Table 1. Shear bond testing- results

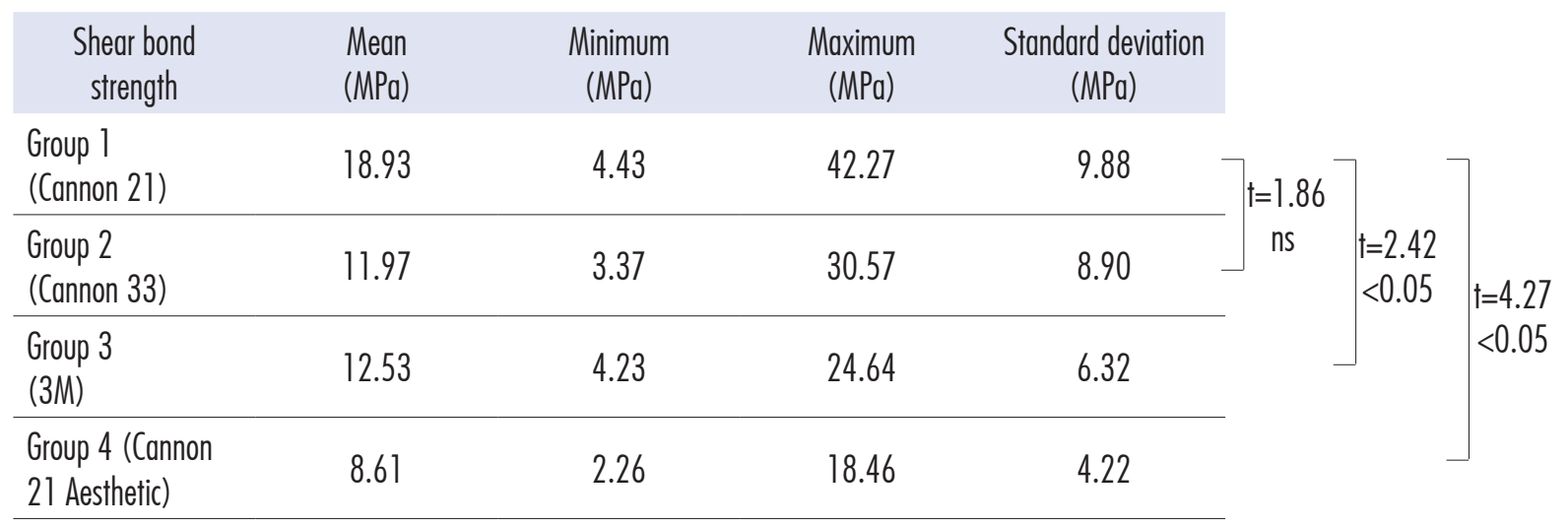

Table 2. Shear bond testing- results. Comparison of new and re-used brackets

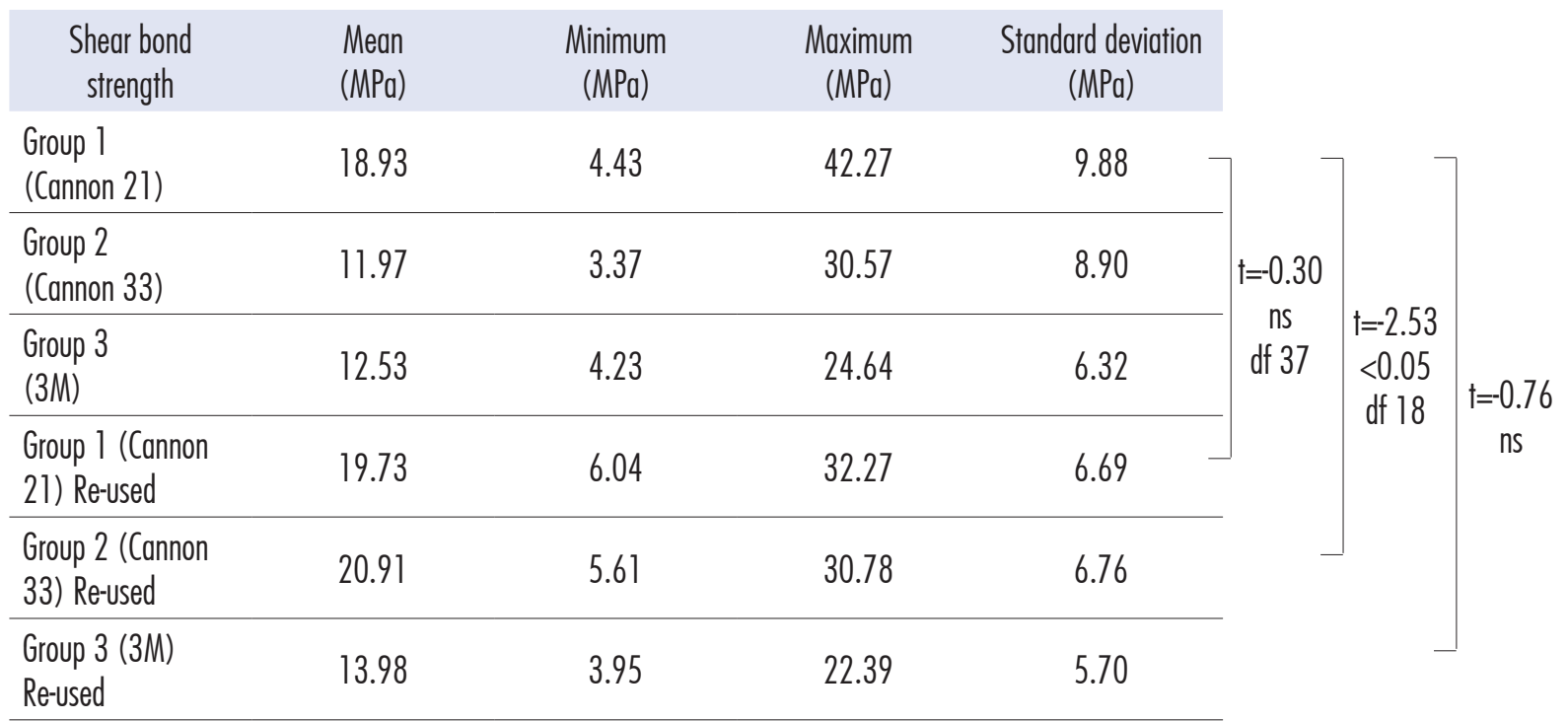

Accepting the results of the Saphiro-Wilk and Levene's test an unpaired Student's t-test was applied to examine intergroup means, the results being presented as $t$ values and the numerical probability of statistical significance.

In the first group, in which Cannon brackets were tested, the mean shear bond strength was $18.93 \mathrm{MPa}$, though with a very wide range from 4.43MPa to $42.27 \mathrm{MPa}$. Considering the results for the lower canine as represented by Group 2 the mean value was lower than in the first group being $11.97 \mathrm{MPa}$, again with a large variation from 3.35 MPa to $30.57 \mathrm{MPa}$. The difference between the two groups was not found to be significantly
Victory Series) średnia siła ścinająca wynosiła $12,53 \mathrm{MPa}$ i była znacząco niższa w stosunku do grupy pierwszej $(\mathrm{t}=2.42 \mathrm{p}<0.05)$. W przypadku zamków estetycznych (kompozytowych) odnotowano statystycznie istotną różnicę w sile wiązania między grupą 1 a $4(\mathrm{t}=4.47 \mathrm{p}<0.05)$. Estetyczne zamki Cannon wykazały najniższe siły wiązania ze średnią wartością $8.61 \mathrm{MPa}(\mathrm{t}=4,27 \mathrm{p}<0,05)$ i zakresem od 2,26MPa do 18,46 MPa.

Efekt oczyszczenia zamków przez wypiaskowanie podstaw został przedstawiony w tabeli 2 , gdzie wartości w MPa dla każdej grupy poddanej wypiaskowaniu zostały porównane z wynikami otrzymanymi w odpowiadającej im grupie no- 
Table 3. Comparisons of adhesive remnant index (ARI) ${ }^{3}$

\begin{tabular}{cccccc} 
Group tested & $n$ & ${ }^{*}$ & ${ }_{1}$ & ${ }^{2}$ & ${ }^{*} 3$ \\
Group 1 (sandblasted) & 20 & 0 & 0 & 1 & 19 \\
\hline Group 2 (sandblasted) & 10 & 2 & 0 & 0 & 8 \\
\hline Group 3 (sandblasted) & 20 & 0 & 9 & 10 & 1 \\
\hline Group 4 & 20 & 18 & 2 & 0 & 0
\end{tabular}

* 0 - less than 10\% of adhesive remaining on bracket;

* 1 - more than $10 \%$ but less than $50 \%$ remaining on bracket;

* 2 - more than $50 \%$ but less than $90 \%$ left on bracket;

$\star 3$ - more than $90 \%$ of adhesive left on bracket.

Table 4. Enamel fracture during debonding

\begin{tabular}{lccccccc} 
& Group 1 & Group 2 & Group 3 & Group 4 & $\begin{array}{c}\text { Group 1 } \\
\text { sandblasted }\end{array}$ & $\begin{array}{c}\text { Group 2 } \\
\text { sandblasted }\end{array}$ & $\begin{array}{c}\text { Group 3 } \\
\text { sandblasted }\end{array}$ \\
\hline $\begin{array}{l}\text { Enamel Fracture } \\
\text { (number of samples) }\end{array}$ & 0 & 0 & 0 & 0 & 9 & 3 & 0 \\
\hline Enamel Fracture (\%) & 0 & 0 & 0 & 0 & 45 & 20 & 0 \\
\hline
\end{tabular}

different $(\mathrm{t}=1.86 \mathrm{~ns})$. The shear bond strength of the third group which comprised more standard edgewise type brackets (3M Victory Series) the mean shear bond strength was $12.53 \mathrm{Mpa}$, which was found to be significantly lower than the first group $(t=2.42 p<0.05)$. In the case of the aesthetic (composite) bracket, a statistically significant difference in shear bond strength between group 1 and group 4 was reported $(t=4.47 \mathrm{p}<0.05)$. The Aesthetic Cannon brackets displayed the lowest bond strength values with a mean value of 8.61 $\mathrm{MPa}(\mathrm{t}=4.27 \mathrm{p}<0.05)$ ranging from $2.26 \mathrm{MPa}$ to $18.46 \mathrm{MPa}$.

The effect of renovation of brackets including the use of sandblasting can be seen in Table 2 where the values of MPa for each tape of bracket after renovation is compared with corresponding values obtained from new brackets. In general, it can be summarized that the re-used brackets demonstrated a slightly higher level of Mpa, though the differences between group means was not found to be significant. wych zamków. Podsumowując można uznać, że zamki poddane piaskowaniu wykazywały wyższe wartości w MPa, aczkolwiek różnice pomiędzy wartościami średnimi obu grup nie były istotne statystycznie.

Wartości odpowiadające wskaźnikowi pozostawionego na zamku kleju (ARI) przedstawia tabela 3 .

Wyniki oceny powierzchni szkliwa badanych próbek (zamki użyte ponownie) zawarte są $\mathrm{w}$ tabeli 4. Wykazano uszkodzenie szkliwa w wyniku debondingu w 9 próbkach grupy 1 (45\%), 2 próbkach grupy 2 (20\%) oraz $0 \mathrm{w}$ grupie 3 (tabela 4 ).

\section{Dyskusja \\ Sila ścinająca}

Aby uniknąć zbędnych awarii podczas leczenia ortodontycznego, system zamek-materiał łączący-szkliwo powinien być w stanie przeciwstawić się siłom żucia, jak również siłom wywieranym przez łuki i/lub wyciągi elastyczne. Jednocześnie połączenie pomiędzy zamkiem a szkliwem musi 
Results of adhesive remnant index (ARI) ${ }^{3}$ are presented in Table 3.

Examination of enamel surface of tested teeth (with re-used brackets) can be seen in Table 4 . The de-bonded brackets revealed enamel fracture in nine samples in group 1 (45\%), two samples in group $2(20 \%)$ and zero in group 3 (Table 4 ).

\section{Discussion}

\section{Shear bond strength}

In order to avoid unnecessary failures in orthodontic therapy the bracket-adhesive-enamel system should be able to withstand the forces of mastication as well as forces exerted by archwires and/or elastic traction. At the same time the bracket/enamel bonding must allow easy and safe removal of the bracket without damage to the tooth surface. ${ }^{13}$ In a previous study, ${ }^{14}$ the optimal bond strength for the clinical use (measured in vitro) has been suggested to be between 6 and $8 \mathrm{MPa}$. It should be emphasized that debonding forces registered in vitro were significantly higher $(11.02 \mathrm{MPa})$ than those measured in vivo $(5.47 \mathrm{MPa})$, where the system is subjected to saliva, acid, masticatory and orthodontic forces. ${ }^{13}$

The main purpose of the present study was to evaluate the efficiency of the bracket base retention and the results suggest that one-piece brackets demonstrate better bonding properties than brackets with foil mesh.

The literature provides inconsistent reports concerning the effect of bracket base designs on the shear bond strength. Sunna and Rock ${ }^{15}$ suggested that there is no significant difference in shear bond strength between brackets with integral bases and mesh-backed brackets, while Regan and Noort ${ }^{16}$ demonstrated that integral cast base produce superior bond strength when compared with a conventional foil-mesh base and integral milled base. Scribante and Sfondrini ${ }^{17}$ demonstrated significantly higher shear bond strength for brackets with anchor pylons than for brackets with foil mesh base.

The 3M Victory Series brackets used as an example of a standard "edgewise" type of bracket displayed a single mesh design with diagonal wires crossing the base from corner to corner. umożliwić łatwe usunięcie zamka, bez szkody dla powierzchni zęba. ${ }^{13}$ Jak sugerują poprzednie badania ${ }^{14}$, optymalne siły wiązania dla zastosowania klinicznego (mierzone in vitro) powinny wynosić między 6 a 8MPa. Należy także podkreślić, że siły odklejania zamka mierzone in vitro były znacząco wyższe niż te mierzone in vivo $(5,47 \mathrm{MPa})$, gdzie system poddawany jest działaniu śliny, kwasu oraz sił okluzyjnych i ortodontycznych. ${ }^{13}$

Głównym celem niniejszego badania była ocena zdolności retencyjnych podstawy zamka. Wyniki wskazują na lepsze właściwości wiążące zamków jednoczęściowych w porównaniu z zamkami z siateczką retencyjną.

Piśmiennictwo dostarcza niespójnych danych dotyczących wpływu budowy zamka na wielkość sił ścinających. Sunna $i$ Rock ${ }^{15}$ podają, że nie ma istotnej różnicy w sile ścinającej dla zamków z podstawą integralną i zamków z siateczką, natomiast Regan i Noor ${ }^{16}$ wykazali wyższe siły wiązania zamków jednoczęściowych $\mathrm{w}$ porównaniu z zamkami z podstawą w postaci siateczki retencynej. Scribante i Sfondrini ${ }^{17}$ wskazują na wyższe siły ścinające dla zamków ze słupkami retencyjnymi w porównaniu z siateczką retencyjną.

Zamki 3M Victory Series użyte jako przykład standardowych zamków typu "edgewise" mają układ pojedynczej siateczki z ukośnym układem drucików, krzyżujących się na podstawie i biegnących do przeciwległych krańców podstawy. Objętość oczek powstałych między tymi drucianymi elementami może odgrywać kluczową rolę w uwalnianiu pęcherzyków powietrza oraz penetracji żywicy w głąb siateczki. Jest to uzasadnione koniecznością eliminacji powietrza podczas wnikania materiału wiążącego pomiędzy siateczkę a podstawę zamka. ${ }^{18}$

Sugerowano także, że zamki z pojedynczą i podwójną siateczką dostarczają porównywalnych sił ścinających oraz mają podobny sposób odklejania. ${ }^{19}$

Zamki jednoczęściowe Cannon Ultra z wbudowanymi słupkami kotwiącymi umożliwiają mechaniczne zablokowanie żywicy w obrębie podstawy zamka, w związku z czym zaleca się mocne dociśnięcie zamka po umieszczeniu go na powierzchni zęba, aby pozwolić na zapłynięcie ma- 
The volume of the apertures created between wire strands may play a critical role in air escape and resin penetration into the mesh. This is justified by the need for effective air escape during adhesive penetration between the mesh and the bracket base. ${ }^{18}$

It has also been suggested that single- and double-mesh bracket bases provide comparable shear bond strengths and bracket failure modes. ${ }^{19}$ Cannon Ultra brackets, a one-piece design with integrated anchor pylons, provide mechanical interlock of the resin in the surface of the base and it is therefore recommended to press the bracket firmly in place after it is positioned on the tooth to allow the adhesive to flow between anchor pylons.

Bonding properties of Cannon bracket for tooth 33 were included in the present study due to high incidence of bonding failures of this bracket during orthodontic treatment. The result of the present study seems to suggest a lower level of force necessary to remove this bracket although the difference between group 1 and 2 in this report (Table 1) was not statistically significant. It is possible that weakness in the bonding of this bracket results from the concave shape of the base and the thicker layer of the adhesive between the bracket base and flat tooth surface (the experimental teeth used in the present report were molar teeth to which the canine brackets have not fitted so closely). To obtain more accurate estimates of bond strength the experiment described in this report should probably be performed on teeth with corresponding shape i.e. on canines.

One clear characteristic of the results of the investigation reported in this paper is the wide range of values for forces necessary to remove bonded brackets, which could be the result of variability in the morphology of the enamel surfaces of the teeth in question.

Comparing metal and aesthetic brackets with integral bases, metal brackets demonstrate considerably better retention properties and it was noticed that bond failure in group 4 was located at the bracket-adhesive interface, which corroborates findings reported in previous studies. ${ }^{20}$ teriału wiążącego pomiędzy wypustki retencyjne. Właściwości wiążące zamków Cannon dla zęba 33 zostały włączone do badania z powodu wysokiej częstotliwości epizodów jego utraty podczas leczenia ortodontycznego. Wynik eksperymentu wydaje się wskazywać na niższe poziomy sił koniecznych do oderwania zamka, mimo że różnica pomiędzy grupą 1 a 2 (Tabela 1) nie była statystycznie istotna. Możliwe, że słabe wyniki tych zamków wynikają z wklęsłego kształtu podstawy i grubszej warstwy materiału łączącego pomiędzy podstawą zamka a płaską powierzchnią zęba (w badaniu wykorzystano trzecie zęby trzonowe, do których zamek dla kła nie przylegał precyzyjnie). Aby uzyskać bardziej miarodajne wyniki sił wiążących, eksperyment powinien być prawdopodobnie przeprowadzony z zastosowaniem korespondujących zębów, czyli kłów.

Jedną z cech charakterystycznych opisanego $\mathrm{w}$ tej pracy badania jest duża rozbieżność wielkości sił potrzebnych do usunięcia przyklejonego zamka, co może wynikać z różnorodności morfologicznej szkliwa wykorzystanych zębów.

Porównując zamki metalowe i estetyczne z podstawami integralnymi, zamki metalowe wykazują znacznie lepsze właściwości wiążące, a ponadto zaobserwowano, że do zerwania w przypadku grupy 4 dochodziło na poziomie zamek/materiał wiążący, co potwierdza ustalenia $\mathrm{z}$ poprzednich badań. $^{20}$

\section{Piaskowanie}

Piaskowanie jest metodą ułatwiającą natychmiastowe ponowne użycie uprzednio utraconego zamka i jest najmniej inwazyjne, jeśli chodzi o powstawanie uszkodzeń podstawy i slotu. Piaskowanie może jednak wpłynąć na właściwości wiążące podstawy zamka.

Poprzednie badania sugerują, że zamki użyte ponownie mogą wykazywać wyższe siły wiążące w porównaniu z nowymi zamkami ${ }^{21}$, podczas gdy inne prace wykazały brak istotnych różnic pomiędzy siłami wiązania metalowych, uprzednio utraconych zamków i nieużywanych zamków. ${ }^{22}$ Williams i Carels $^{23}$ zauważyli, że efekt piaskowania różnił się w zależności od rodzaju zamka i był istotny jedynie w przypadku zamków z podsta- 


\section{Sandblasting}

Sandblasting is a method facilitating the immediate re-use of the previously failed bracket and is least likely to damage the bracket base and distort the slot. Sand blasting can, however, alter bonding properties of the bracket base.

In a previous report it has been suggested that re-used brackets can demonstrate higher shear bond strength than new brackets ${ }^{21}$ though other studies showed that bond strengths of previously failed bonded metal brackets were not significantly different from bond strengths of new brackets. ${ }^{22}$ Williams and Carels $^{23}$ reported that the effect of sandblasting depends on the bracket type and was significant only in the case of brackets with integral bases (increase in shear bond strength). The design of integral bracket base allows for an increase in surface roughness and complete removal of the resin. In mesh brackets it is possible that particle size of the abrasive is too large to completely remove adhesive remnants creating less retentive surface for adhesion.

The present study demonstrates no statistically significant difference between the shear bond strength of re-used and new brackets from group 1 and 3. On the other hand, sandblasting significantly improved bonding properties of brackets from group 2. It should also be emphasized that this finding must be interpreted with care since it is not certain that the bracket bases themselves are unchanged after the first period of use.

The site of failure during debonding also provides relevant information about the bonding process. Examination of bracket bases revealed differences in location of the residual bonding material (Table 3 and Figure 7). In Cannon groups in almost all samples more than $90 \%$ of the adhesive remained on the bracket (it indicates

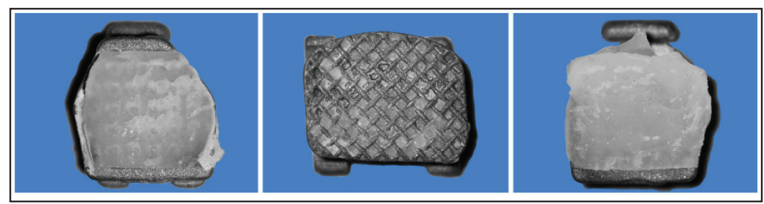

Fig. 7. Brackets form Group I, Group 3, Group 2 (brackets re-used, sandblasted before bonding).

Zamki z Grupy 1, Grupy 3, Grupy 2 (zamki po powtórnym użyciu, piaskowane przed przyklejeniem).

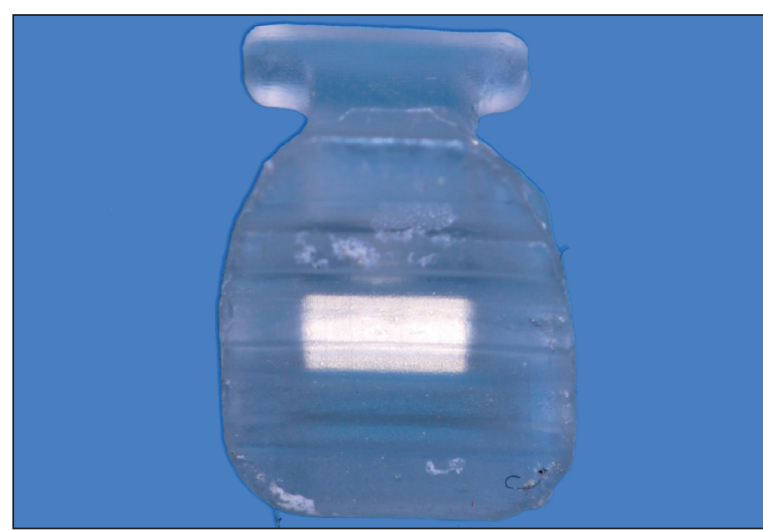

Fig. 6. Bracket from Group 4 (aesthetic brackets) after debonding. Almost no adhesive visible on the bracket surface.

Zamek z Grupy 4 (zamki estetyczne) po oderwaniu. Materiał wiqzżacy niemal nieobecny na powierzchni zamka.

wą integralną (wzrost siły wiązania). Architektura podstawy zamka tego typu pozwala na zwiększenie szorstkości jej powierzchni oraz całkowite usunięcie żywicy. W przypadku zamków z siateczką retencyjną prawdopodobnie wielkość cząsteczek środka abrazyjnego jest zbyt duża, by dokładnie usunąć pozostałości materiału łączącego, który tworzy mniej retencyjną dla adhezji powierzchnię.

Powyższe badanie wykazało brak statystycznie istotnych różnic w wielkości sił ścinających zamków użytych ponownie i nowych zamków grup 1 i 3. Z drugiej strony, piaskowanie znacząco polepszyło właściwości wiążące zamków z grupy 2 .

Należy podkreślić, że wyniki te trzeba interpretować $\mathrm{z}$ dużą dozą ostrożności, ponieważ nie jest wykluczone, że podstawy zamków zostały zniekształcone podczas pierwszego cyklu użytkowania.

Także miejsce zerwania połączenia dostarcza istotnych informacji na temat procesu wiązania. Badanie podstaw zamków wykazało różnice

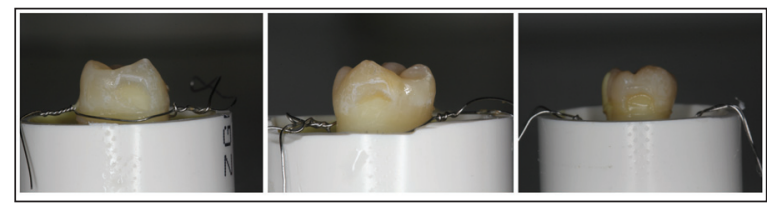

Fig. 8. Enamel fracture after debonding of re-used sandblasted brackets with integral bases.

Uszkodzenia szkliwa po oderwaniu zamków z podstawą integralnq po wypiaskowaniu i powtórnym użyciv. 
the failure on the enamel-adhesive level or even within the enamel), while in group 3 fracture took place mainly between the bracket base and the adhesive indicating the lowest bond strengths and worst retentive capacity of sandblasted mesh brackets.

\section{Enamel cracking}

Groups 1 and 2 after sandblasting displayed a relatively high frequency of enamel fracture on debonding (Table 4, Fig. 8), which corroborates scores obtained in a study presented by Hobson. ${ }^{24}$ Forces larger than $17 \mathrm{MPa}$ are excessive for orthodontic use, and result in a significantly higher risk of enamel fracture.

Rix $^{5}$ observed that the greatest frequencies of enamel fracture upon debonding occurred in groups demonstrating the highest bond strengths.

\section{Conclusions}

1. Brackets with integral bases demonstrate better bonding properties than brackets with foil mesh.

2. Metal brackets with integral base demonstrate better bonding properties than plastic brackets.

3. There is no statistically significant difference between the shear bond strength of re-used and new brackets with foil mesh and brackets with integral bases.

4. Metal brackets with integral bases displayed a high frequency of enamel fracture on debonding of re-used sandblasted brackets. w rozmieszczeniu pozostałego materiału łączącego (tabela 3 i rycina 7). W grupie z zamkami Cannon w niemal wszystkich przypadkach $90 \%$ kleju pozostawało na zamku (wskazuje to na miejsce zerwania połączenia na poziomie szkliwo/ materiał łączący lub nawet w obrębie szkliwa), podczas gdy w grupie 3 złamanie miało miejsce głównie pomiędzy zamkiem a materiałem łączącym, wskazując na najniższe siły wiązania i najgorsze właściwości retencyjne wypiaskowanych zamków z siateczką.

\section{Pęknięcia szkliwa}

Grupy 1 i 2 po wypiaskowaniu wykazały relatywnie wysoką częstotliwość uszkodzeń szkliwa podczas odklejania zamków (Tab.4, Fig.8), co potwierdza wyniki otrzymane $\mathrm{w}$ badaniu prezentowanym przez Hobsona ${ }^{24}$. Siły większe niż $17 \mathrm{MPa}$ są nadmierne dla celów leczenia ortodontycznego i skutkują znacząco wyższym ryzykiem uszkodzenia szkliwa.

Rix ${ }^{5}$ odnotował, że częściej do uszkodzeń szkliwa podczas usuwania zamków dochodziło w przypadku grup wykazujących najwyższe siły wiążące.

\section{Wnioski}

1. Zamki z podstawami integralnymi wykazują lepsze właściwości wiążące w porównaniu z zamkami z siateczką integralną.

2. Metalowe zamki z podstawą integralną wykazują lepsze właściwości wiążące niż zamki plastikowe.

3. Nie ma statystycznie istotnej różnicy pomiędzy siłą ścinającą zamków użytych ponownie oraz nowych zamków z siateczką retencyjną i podstawą integralną.

4. Zamki metalowe z podstawą integralną wykazały większą częstość uszkodzeń szkliwa podczas odrywania ich po uprzednim użyciu i wypiaskowaniu. 


\section{References}

1. Tamizharasi, Kumar S: Evolution of orthodontic brackets. JIADS 2010; 1: 25-30.

2. Wang WN, Li CH, Chou TH, Wang DD, Lin LH, Lin $C T$ : Bond strength of various bracket base designs. Am J Orthod Dentofacial Orthop 2004; 125: 65-70.

3. Sorel O, El Alam R, Chagneau F, Cathelineau G: Comparison of bond strength between simple foil mesh and laser-structured base retention brackets. Am J Orthod Dentofacial Orthop 2002; 122: 260266.

4. Algera TJ, Kleverlaan CJ, Prahl-Andersen B, Feilzer AJ: The influence of different bracket base surfaces on tensile and shear bond strength. Eur J Orthod 2008; 30: 490-494.

5. Rix D, Foley TF, Mamandras A: Comparison of bond strength of three adhesives: Composite resin, hybrid GIC, and glass-filled GIC. Am J Orthod Dentofacial Orthop 2001; 119: 36-42.

6. Sharma S, Tandon P, Nagar A, Singh GP, Singh A, Chugh VK: A comparison of shear bond strength of orthodontic brackets bonded with four different orthodontic adhesives. J Orthod Sci 2014; 3: 29-33.

7. Toledano $M$, Osorio $R$, Osorio E, Romeo A, Higuera B, Garcia-Godoy F: Bond strength of orthodontic brackets using different light and selfcuring cements. Angle Orthod 2003; 73: 56-63.

8. Horng D, Hsiang T: Bond strength of younger and older permanent teeth with various etching time. Angle Orthod 1993; 63: 225-230.

9. Parker WS: A Consideration of the Pure Begg Technique. Angle Orthod 1969, 39: 1-10.

10. Shapiro SS, Wilk MB: An analysis of variance test for normality (complete samples). Biometrika 1965; 52: 591-611.

11. Levene $H$ : Robust tests for equality of variances. In Ingram Olkin; Harold Hotelling; et al. Contributions to Probability and Statistics: Essays in Honor of Harold Hotelling. Stanford University Press; 1960. p. 278-292.

12. Student: The probable error of a mean. Biometrica 1908; 6: 1-25.

13. Pickett KL, Sadowsky PL, Jacobson A, Lacefield $W$ : Orthodontic in vivo bond strength: comparison with in vitro results. Angle Orthod 2001; 71: 141148.

14. Clark SA, Gordon PH, McCabe JF: An ex vivo investigation to compare orthodontic bonding using a 4-META based adhesive or a composite adhesive to acid etched and sandblasted enamel. J
Orthod 2003; 30: 51-58.

15. Sunna $S$, Rock WP: An ex vivo investigation into the bond strength of orthodontic brackets and adhesive systems. Br J Orthod 1999; 26: 47-50.

16. Regan D, Noort R: Bond strength of two integral bracket-base combinations: an in vitro comparison with foil-mesh. Eur J Orthod 1989; 11: 144-153.

17. Scribante A, Sfondrini MF, Fraticelli D, Daina $P$, Tamagnone $A$, Gandini $P$ : The influence of no-primer adhesives and anchor pylons bracket bases on shear bond strength of orthodontic brackets. Biomed Res Int 2013; 2013: 315023. doi: $10.1155 / 2013 / 315023$.

18. Mac Coll GA, Rossouw PE, Titley KC, Yamin $C$ : The relationship between bond strength and orthodontic bracket base surface area with conventional and microetched foil-mesh bases. Am J Orthod Dentofacial Orthop 1998; 113: 276-281.

19. Bishara SE, Soliman MM, Oonsombat C, Laffoon $J F$, Ajlouni R: The effect of variation in mesh-base design on the shear bond strength of orthodontic brackets. Angle Orthod 2004; 74: 400-404.

20. Liu JK, Chuang SF, Chang CY, Pan YJ: Comparison of shear bond strengths of plastic and metal brackets. Eur J Orthod 2004; 26: 531-534.

21. Sharma-Sayal SK, RossouwPE, Kulkarni GV, Titley $K C$ : The influence of orthodontic bracket base design on shear bond strength. Am J Orthod Dentofacial Orthop 2003; 124: 74-82.

22. Sonis AL: Air abrasion of failed bonded metal brackets: a study of shear bond strength and surface characteristics as determined by scanning electron microscopy. Am J Orthod Dentofacial Orthop 1996; 110: 96-98.

23. Willems $G$, Carels $C E$, Verbeke G: In vitro peel/ shear bond strength evaluation of orthodontic bracket base design. J Dent 1997; 25: 271-278.

24. Hobson RS, Ledvinka J, Meechan JG: The effect of moisture and blood contamination on bond strength of a new orthodontic bonding material. Am J Orthod Dentofacial Orthop 2001; 120: 54-57.

Address: 31-155 Kraków, ul. Montelupich 4

Tel.: +4812 4245402, Fax: +48124245494

bwloster@gmail.com

Received: $7^{\text {th }}$ July 2016

Accepted: $7^{\text {th }}$ January 2017 